\title{
Albanians in Presevo Valley and Their National Rights
}

\author{
Dr.Sci.Veton Zejnullahi
}

\begin{abstract}
The situation of Albanians in Serbia, especially in three municipalities bordering with Kosovo-Presevo, Bujanovac and Medvegja, which are known as the Presevo Valley region remains the same even after the Kosovo war and after the war that took place in this region between Serbian government forces and ethnic Albanian fighters LAPMB. Since in this region the majority of the population is Albanian, then the object of study will be focused in the situation of the population there and the challenges facing it in everyday life and problems they encounter, starting from the most basic ones like: education, information, health, use of language, use of national symbols and many other problems. Presevo Valley throughout the stages of its history has always been marked with the various tensions depending on the circumstances, which have escalated to armed conflicts as happened during World War II when fighters of this area contributed greatly to the fight against fascism and Nazis, but even in the latter case when the war took place between government forces and ethnic Albanian Serbian organized around LAPMB. We will also see that the Albanian population in this region is indigenous to the early centuries of history being part of the Ancient Dardania and despite many invaders, Albanian population managed to preserve its national identity. Therefore the aim of this paper is to show the state of Albanians in the Presevo Valley focusing on historical, political, economic, demographic, cultural, educational, health, national rights - the symbols and language, information, migration and many problems other faced by the people of this region.
\end{abstract}

Keywords: Presevo Valley, national rights, war of LAPMB, Albanians, World War II

\section{Introduction}

Albanian Presevo Valley region in southern Serbia itself includes three Albanian municipalities Presevo, Bujanovac and Medvedja, in ancient times, the region of the Presheva Valley has been under Roman domination. Until the IX-th century, the region of the Presheva Valley remained under Bizant occupation. From the second half of the IX-th century until the Xth century the region was occupied by the Bullgarien kingdom. From the XI-th century until the XII-th century Presheva Valley was under the Bizant occupation. At the end of the XII-th century, due to the Serbian documents, the region was invaded by The Nemaniq until the year 1455. During this period of time, autochthonous population pertained Christian religion propagated by Roman Empire.

Presheva during the period of Turkish dominance in the Balkan was included to Shkupi territory. The national structure in this area was almost with 100\% Albanians. A massive part of Albanians from the North-East area of Arberia (Vranja, Leskovci, Nishi, Piroti, Surdulica etc) were displace during proclamation of Serbia independence from Turkish Empire. As a proof (evidence) of this displacement is the fact that many families and people of the villages nowadays can still tell about their origin from the North-East area of Arborio.

After the Congress of Berlin, Kazaa Presevo, from 1878 belonged to the Pristine Sandzak Vilayet of Kosovo ${ }^{1}$ and it included Nahinë of Bujanovac and Trgoviste until 1912, when Presevo was included in Serbia.

In the Serbian Kingdom, Croats and Slovenes, established in 1918, Presevo district belonged to the Banovina of Vardar Skopje, Kumanovo district until 1946, when Presevo, arbitrarily and without the will of the Albanian people and the purpose of assimilation and narrowing of ethnic surface was divided from Kosovo and Macedonian Albanians, in order to put control from the top, from the district of Vranje and Leskovac at times of the former Yugoslavia. ${ }^{2}$

\footnotetext{
${ }^{1}$ Skender Latifi, Rrugëtimi nëpër Luginë të Preshevës, Preshevë, 2006

${ }^{2}$ www.kosovalindore.com 
The region of the Presheva Valley is inhabited with a majority of Albanian population. Since in ancient time it was part of Dardania territory. The historical truth that the region of Presheva, Bujanoci and Medvegja shows geopolitical and geographical land integrity with Kosova, derive from archive data presenting this region always as inseparable part of the Kosovo Vilayet

\section{Map of the Albanian's Vilayet ${ }^{1}$}

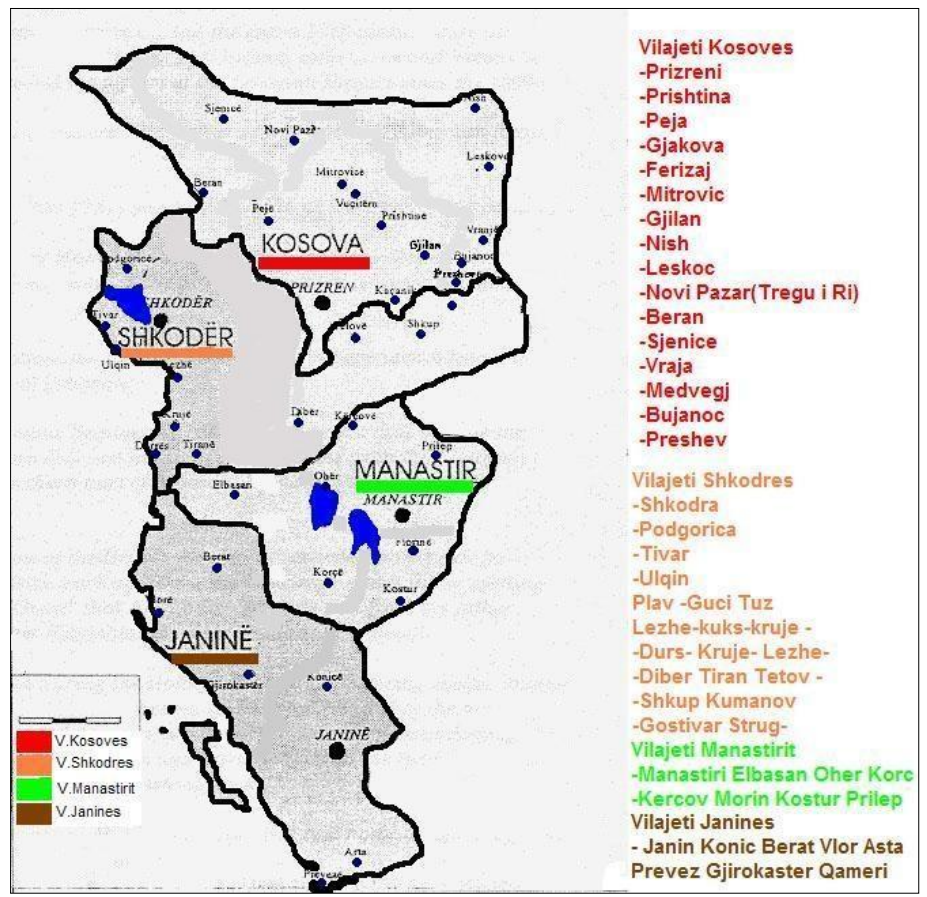

In the map clearly shows that the Presevo Valley belonged to the Vilayet of Kosovo since old times.

\section{The ethnic structure in the Presevo Valley}

In the Presevo Valley region there is an ethnically mixed structure consisting of several people as Albanians, Serbs, and Roma etc. Region staffed with about 100,000 inhabitants according to the census of 1991 of which $67 \%$ are Albanians, whereas according to the 2002 census live approximately 90,000 inhabitants, of which $65 \%$ Albanians. Looking to a decrease in the number of residents, and especially the number of Albanians linked especially with massive displacement from Medvedja in Kosovo, and the highland of Presevo and Bujanovac as a result of the establishment of Serbian forces expelled from Kosovo after the 1999 war.

Statistical data from the Census of years 1991 dhe $2002{ }^{2}$

\footnotetext{
${ }^{1}$ www.presheva.com

${ }^{2}$ http://sr.wikipedia.org/wiki/Попис становништва 1991. у СФРJ http://sr.wikipedia.org/wiki/Попис_становништва_2002._у_Србији 


\begin{tabular}{|l|r|r|r|r|r|r|}
\hline \multirow{2}{*}{ Structure of population } & \multicolumn{2}{l|}{ llajanoc } & \multicolumn{2}{l|}{ Medvegja } \\
\cline { 2 - 7 } & 1991 & 2002 & 1991 & 2002 & 1991 & 2002 \\
\hline \multirow{3}{*}{ Albanians } & 34.992 & 31.098 & 29.588 & 23.681 & 3.832 & 2.816 \\
\hline \multirow{3}{*}{ Serbian } & $89.95 \%$ & $89,09 \%$ & $60.09 \%$ & $54.69 \%$ & $28.67 \%$ & $26.17 \%$ \\
\hline \multirow{3}{*}{ Roma } & 3.206 & 2.984 & 14.660 & 14.660 & 8.194 & 7.163 \\
\cline { 2 - 8 } & $8.23 \%$ & $8,55 \%$ & $29.58 \%$ & $34.14 \%$ & $61.30 \%$ & $66.57 \%$ \\
\hline \multirow{3}{*}{ Others } & 505 & 322 & 4.408 & 4.408 & 119 & 109 \\
\cline { 2 - 7 } & $1.30 \%$ & $0.92 \%$ & $8.95 \%$ & $8.93 \%$ & $0.89 \%$ & $1.00 \%$ \\
\cline { 2 - 7 } & 240 & 240 & 582 & 582 & 1223 & 1.223 \\
\cline { 2 - 7 } & $0.62 \%$ & $0.62 \%$ & $1.18 \%$ & $1.18 \%$ & $9.15 \%$ & $9.15 \%$ \\
\hline
\end{tabular}

\begin{tabular}{|c|c|c|c|c|}
\hline Structure of population & $\begin{array}{l}\text { Number of inhabitants } \\
1991\end{array}$ & $\%$ & $\begin{array}{l}\text { Number of inhabitants } \\
2002\end{array}$ & $\%$ \\
\hline Albanians & 68.412 & 67 & 56.595 & 63 \\
\hline Serbs & 26.060 & 26 & 24.807 & 28 \\
\hline Roma & 5.032 & 5 & 4.839 & 5 \\
\hline Others & 2.045 & 2 & 2.045 & 4 \\
\hline & 101.549 & 100 & 88.286 & 100 \\
\hline
\end{tabular}

In these results are not included around to 25,000 Albanians who live in the west as well as in Kosovo. 


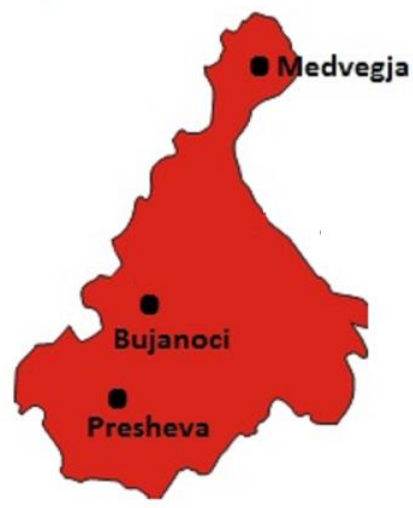

Map of the Presevo Valley ${ }^{1}$

\section{Current problems in the Presevo Valley}

Even after the war and reaching political agreement, the Presevo Valley and Albanian citizens are faced with many problems that are the basic terms of national rights. The problem that worries is that of higher education in the native language, so the lack of a University which could meet the needs of the Valley with new cadres. This region is known as a very strong educational and argued that the first school was opened in 1892 although distant learning took place not in Albanian language, while the first Albanian school opened with the 7 Feb. 1945.

Today the youth and the population as a whole suffers from political problems between Kosovo and Serbia regarding acceptance of diplomas, every days we sow the young Albanian are going to the UNMIK office in Pristina to the sealing of degrees to be valid in Serbian state.

So the only option is to study in Pristina, Tirana and Tetovo. Even after many requests still not opened any institution of higher education in the Valley.

Another problem is the health because there is no single hospital in the region except for a certain number of ambulances that in no way do not meet the needs, so for any serious health problem people have to deal with tens of kilometers to receive the needed medical services. Also the information situation in their mother tongue is not good, where is no information, besides several local television there is no television or newspaper which would cover the entire territory in order to inform as quickly and efficiently to citizens.

Albanian citizens are deprived of their right to use their national symbols such as the use of the national flag and official use of Albanian language.The official documents today are issued only in Serbian and Albanians do not enjoy any right in this regard.

But obviously very disturbing problem is the demilitarization of the area which is provided with Koncul Agreement.I this area , is not that there is going demilitarization but rather the region has never been more militarized because in this region operate in addition to the regular police also Serbian special forces called (xhandamëria) and here has established a large military base, one of the largest Serb army. Therefore it is reasonable fear citizens of any potential violence are from these forces. Besides the police where representation is somewhat pleasing Albanians are not represented in these bodies and in their judicial system percentage is very small and not used the Albanian language as an official language.

${ }^{1}$ http://lajme.dervina.com/foto/0502244811716e693be8c0228dadcdd3/hartaluginapreshevbuja novc1A[1].jpg 
Currently the most preoccupying problem of this region is a migration which has taken over, especially after the visa liberalization that the EU decided to Serbia. The causes of this migration are numerous ranging from security issue that led to massive displacement from Medvedja and Presevo and Bujanovac Highlands immediately after the Kosovo war, then to the lack of prospects and economic development of this region and makes that Albanian youth which are educated in Kosovo or Albania in the absence of perspective remain there because the opportunity for employment is greater, and according to the testimony of people from Presevo and Bujanovac has been continually departing buses with citizens who has beset Western countries especially Belgium and the Netherlands in search of better conditions of life. Assumption that only in Kosovo and Western Europe over 25,000 Albanian citizens from Presevo Valley that when apportioned to the total number would mean some $25 \%$ of the general population.

\section{Economic development perspective}

Presevo Valley region except its important geo-strategic terms it is rich in underground and provides favorable conditions for economic development. The main branch of the economy is agriculture and this region is known for the cultivation of different crops but is characteristic tradition of tobacco cultivation. In the industrial region has been dependent Serbian industry through factories raised in the Presevo Valley where the processing of wood, crystal, paper, metal and tobacco but which are now out of order.

A very important branch is the tourism since the Presevo Valley provides conditions for its development, especially through two spas: Spas of Bujanovac where their processing of known mineral water "Heba" and Medvedja Sijarin spa rooms.

Given the geo-strategic position, corridor E-10, likely regional ties, new age population and foreign investment necessary for Presevo Valley region could have a rapid economic development.

\section{Conclusions and Recommendations}

- Albanians must establish National Council and choose all its structure starting with the Council assembly. The role of the National Council should be Government in shadow for the Presheva Valley

- National Council to frame development politics for economy, politic, education and health

- National Council to frame projects for inauguration of one high institution for education and the inauguration of hospitals

- Establishment of the news agency, radio television and daily newspaper with the intention of informing the internal as well as external opinion

- $\quad$ National Council to require from two Albanian states (the Republic of Albania and the Republic of Kosovo) to open offices in the Presheva Valley respectively in Tirana and Pristine with trade character

- National Council to require from the Government of Kosovo and international factions to provide for the Albanians from the valley the right of two state statuses as it was provided to Serbians from Kosovo.

- The regionalization of the Presevo Valley that would allow special status of political, administrative, etc., a position which would improve the position of Albanians in Presevo Valley in particular in relation to the treatment of the Republic of Serbia for this region.

- $\quad$ Reciprocity in the provision of minority rights, the Presevo Valley Albanians from Serbia in relation to the rights that the Republic of Kosovo has given the Serbian minority in Kosovo, as a condition for Serbia on its path towards EU integration, considering that the treatment of the rights and guarantees for minorities remains among the conditions for integration not only for Serbia and the Balkans but across Europe.

- Organization of a regional and international conference of donors and potential investors that will enable economic development Presevo Valley, a step that would open the way to further development in all areas 
taking into account the importance of economic development and impact its sectoral policies that would increase the number of employees as well as social welfare of citizens.

- Institutional and social Cooperation in all possible areas of cooperation and all levels of representation with the Republic of Kosovo, the Republic of Albania, Albanian Diaspora, the Albanians of Macedonia and Montenegro Albanians.

- $\quad$ Opening of higher education institutions with regional and international character which will enable not only national integration of Albanians from all Albanian territories but also the citizens of neighboring countries by promoting regional cooperation as a condition for European integration and prevention the conflict.

- Urbanization Presevo Valley as a precondition for tourism development and promotion of the latter as an opportunity for growth and increasing living standards.

\section{Bibliography}

[1] Skender Latifi, Rrugëtimi nëpër Luginë të Preshevës, Preshevë, 2006

[2] Lisen Bashkurti, Krizat Ndërkombëtare, Tiranë, 2008

[3] Srbija i Albanci, knjiga prva,Ljubljana, 1989

[4] Gazeta Bota sot 25.08.2000,fq.4

[5] Zakon o Lokalnoj Samoupravi Republike Srbije: neni 63, paragrafi 2

[6] http://www.europeanforum.net/news/701/ethnic_albanian_rsquo_s_propose_regionalisation_of_pre_scaron_e vo_valley_region

[7] http://sr.wikipedia.org/wiki/Попис становништва 1991. у СФРЈ

[8] http://sr.wikipedia.org/wiki/Попис_становништва_2002._у_Србији

[9] http://lajme.dervina.com/foto/0502244811716e693be8c0228dadcdd3/hartaluginapreshevbujanovc1A[1].jpg

[10] http://www.kt.gov.rs/t/articles/presheva/

[11] www.presheva.com

[12] www.kosovalindore.com

\section{The literature consulted}

[1] Hysen Ahmeti,Konçuli gjatë historisë MONOGRAFI, Gjilan 2004

[2] Nehat Sadiku, Kosova,llirida dhe Kosova Lindore 1989-2003

[3] Abaz Lleshi, Gjeopolitika e Ballkanit dhe perspektivat e sigurisë në rajon Tiranë 2009

[4] Gert-Heinrich Ahrens,Diplomaci mbi tehun e thikës,Tiranë 2010 